\title{
Eclesiásticos criollos en la Capilla Real de Palacio: una elite de poder en el reinado de Carlos II (1665-1700) ${ }^{1}$
}

por

Juan A. Sánchez Belén

UNED

\begin{abstract}
El presente artículo analiza las razones que llevaron a las elites criollas de los virreinatos americanos a solicitar empleos de capellanes de honor y de predicadores reales en la Capilla Real de Palacio en las décadas finales del siglo XVII, asi como el estudio de los mecanismos de selección establecidos por la Corona para facilitar su acceso a la institución, especialmente los relacionados con la limpieza y nobleza del linaje de los aspirantes a una de esas plazas.
\end{abstract}

Palabras clave: eclesiástico; criollo; elites; Capilla Real; Carlos II .

\section{INTRODUCCIÓN}

Durante la Edad Moderna se produce un fluido intercambio, y no sólo comercial, entre España y los reinos del Nuevo Mundo. En el plano administrativo y político, también en el eclesiástico, este flujo adquirió una gran intensidad aunque con frecuencia en una única dirección, desde la metrópoli hacia los virreinatos de América, pues habitualmente los empleos principales de la administración virreinal y de la Iglesia recayeron en súbditos españoles, aun cuando, por su carácter de monarquía compuesta, los hubo originarios de los territorios europeos (Milán, Nápoles, Cerdeña, Sicilia, Países Bajos) suje-

${ }^{1}$ El trabajo se inscribe en el proyecto de I+D HAR 2011-22425 del Ministerio de Ciencia e Innovación con el título "Poder político y poder simbólico en la Corte española: Las Casas Reales en los siglos XVII y XVIII". 
tos a la rama española de los Habsburgo. No obstante, a partir del siglo XVII empezará a ser constante la presencia en la Corte de individuos nacidos en las principales ciudades de los virreinatos de Perú y de Nueva España que deseaban ocupar empleos en las Audiencias y en el gobierno municipal, lo que conseguirán gracias en parte a la venalidad de los oficios; tendencia que proseguirá en la primera mitad del siglo XVIII, pues el 35 por ciento de las provisiones de empleos públicos para el territorio de la Audiencia de Quito recayó en criollos y el resto en españoles peninsulares ${ }^{2}$. Este asalto se aprecia asimismo en ciertas comunidades religiosas, ya que su elevada participación les llevará, por un lado, a protagonizar frecuentes altercados con los españoles con la finalidad de hacerse con su $\operatorname{control}^{3}$, y por otro a marginar a los mestizos en beneficio propio, como acontece en la Compañía de Jesús del virreinato peruano ${ }^{4}$.

El presente estudio intenta establecer, a través de la Capilla Real de Palacio, un nexo de unión poco conocido o infravalorado entre ambos mundos separados por el Atlántico, confirmando con ello la progresiva integración de los naturales americanos en los diferentes ámbitos de la Monarquía Hispánica, así como la movilidad que existía en la época a pesar de las distancias y de los peligros de la navegación. Porque a partir de la década de 1650 y hasta el final del reinado de Carlos II, período en el que se sitúa esta investigación, ciertos personajes criollos, tras formarse intelectualmente en sus lugares de origen y desempeñar cargos de responsabilidad en el seno de la Iglesia americana, serán promovidos a una plaza de capellán de honor o de predicador en la Capilla Real de Palacio, punto de inflexión en sus trayectorias personales. Las páginas que siguen buscarán poner, si no rostro, si al menos nombre y currículum a los individuos de esa elite criolla que vinculaba su progreso social y político al destino de la corona, a la que sirven y de la que esperan una recompensa adecuada a sus méritos y a su linaje, para lo cual se analizarán sus orígenes geográficos y los de su familia, así como su procedencia social, las redes clientelares y regionales en las que estaban inmersos, su cursus honorum y su promoción posterior a la obtención del empleo de predicador real o de capellán de honor.

\footnotetext{
2 Sanz Tapia, 2009; 2000: 161-180; 2006: 49-73. García Bernal, 2000: 89-110.

3 Rubial García, 1990. Luna Moreno, 1993: 55-72.

4 Coello de la Rosa, 2008: 37-66.
} 


\section{LA CAPILla REAL DE PALACIO DE MADRID: COMPOSICIÓN Y MECANISMOS DE ACCESO A LAS PLAZAS DE CAPELLÁN DE HONOR Y DE PREDICADOR REAL}

La Real Capilla era uno de los varios departamentos que configuraban el entramado de lo que se ha dado en llamar las Casas Reales, junto con la Casa y la Cámara del Rey, la Casa y la Cámara de la Reina, la Casa de los Príncipes y las Caballerizas Reales ${ }^{5}$. Pero si las otras dependencias palatinas tenían como finalidad atender a los reyes en sus necesidades personales, la principal función de la Capilla Real era la de proporcionar el alimento espiritual de los soberanos y solemnizar el culto divino ante las personas reales, su familia y los cortesanos; también tenía el cometido de conferir a las ceremonias litúrgicas una proyección, con fines políticos y propagandísticos, de la majestad real a través de la sacralización del soberano y de su dinastía; y era, finalmente, el marco institucional adecuado para quienes desde el púlpito deseaban denunciar, al modo de San Juan Bautista frente a Herodes, no sólo los vicios y males de la república, sino la misma gestión de los gobernantes ${ }^{6}$.

A partir del asentamiento en 1561 de la Corte en Madrid, la Real Capilla va a disponer de un espacio físico propio donde desarrollar sus funciones. Ello implicará además la desaparición de los constantes roces y conflictos de jurisdicción que hasta entonces se habían suscitado entre el Capellán Mayor y los prelados de las diócesis en las que se instalaba la Corte, dado su carácter itinerante, a pesar de que las Bulas papales reconocían su independencia, y en particular de la del arzobispo de Toledo, a cuya diócesis pertenecía la «coronada» villa de Madrid?.

Desde que fuera erigida, la institución disponía de un corpus normativo y de unas atribuciones propias que serán recopilados, para el caso de la Corona de Castilla, por Juan II en 1436, en donde se establecían sus obligaciones, jerarquía de sus criados y funcionamiento general ${ }^{8}$, mientras que los monarcas aragoneses, en la Capilla Real que instituyeron en la Corona de Aragón, adoptaron las constituciones y el ceremonial de la corte papal de Aviñon. La normativa de Juan II de Castilla, ratificada en 1486 por los Reyes Católicos,

\footnotetext{
5 Gómez-Centurión Jiménez y Sánchez Belén, 1996: 157-175.

6 Álvarez-Osorio Alvariño, 2004: 99-123. Para una época anterior, Negredo del Cerro, 2001: 323-344 y 2006.

7 Informe a Felipe V sobre la jurisdicción de la Capilla Real, s.a. Archivo General de Simancas, Valladolid (AGS), Gracia y Justicia, 928.

8 Constituciones de la Capilla de don Juan II de Castilla, 1436, Archivo General de Palacio, Madrid (AGP), Administrativa, 1133.
} 
se mantendrá sin cambios sustanciales hasta la muerte de Isabel la Católica9, ya que a partir de entonces sus sucesores, Juana I y Felipe de Habsburgo, introducirán las primeras modificaciones con aspectos y ritos incorporados de la Capilla Real de la Casa de Borgoña, si bien no será hasta la entronización de Carlos I cuando el ceremonial borgoñón comience a adquirir mayor peso. Con todo, el Emperador mantendrá en líneas generales la organización de la Capilla heredada de sus abuelos, destinada sólo al servicio de la Emperatriz, en su calidad de Regente del reino, y del Príncipe Felipe, mientras que en sus constantes viajes conservará el organigrama de la Capilla de Borgoña, con sus dos departamentos: la grande chapelle, a cuyo frente estaba el premier chapelain, y la petite chapelle, dirigida por el grand et premier aumônier du roi ${ }^{10}$.

Los rasgos que pervivieron desde el siglo XV en la Real Capilla y las modificaciones sucesivas, que en muchos casos sólo eran añadidos que en poco alteraban su estructura y organización, se oficializan con Felipe II, quien unifica criterios para organizar la Capilla «al modo de Castilla y de Borgoña». Si al frente de la Capilla estaba el Capellán Mayor, cargo tradicional de la Capilla castellana, un Limosnero Mayor, proveniente de la Capilla borgoñona, será la persona encargada de cubrir las ausencias y faltas del primero. Por otra parte, y hasta finales del siglo XVI, esa dualidad de capillas se observa sobre todo en que mientras el banco de capellanes, propio de la Capilla de Castilla, servía los oficios religiosos en los oratorios privados familia real y tenía la obligación de asistir a las grandes celebraciones eclesiásticas, el grueso de los servicios religiosos -el culto divino- recaía en los capellanes de altar, heredados de la tradición flamenca, quienes oficiaban, cantaban canto llano e, incluso, polifonía junto a los cantores bajo la dirección de un Maestro de Capilla ${ }^{11}$.

En 1623 Felipe IV aprueba unas Constituciones para la Capilla Real que se mantendrán en vigor hasta las reformas promulgadas en 1749 por Fernando $\mathrm{VI}^{12}$. La nueva normativa venía a regular de forma clara las funciones de los diferentes criados que la integraban (Capellán Mayor, Receptor, Juez, Cura, Maestro de Ceremonias, Sumilleres de Cortina, Capellanes de honor, Músicos y otros criados), a la vez que se determinaban las funciones de nuevos empleos (sumilleres y furrieres). La principal novedad es que el Capellán

9 Constituciones de los Reyes Católicos, 7 de agosto de 1486, AGP, Administrativa, 1133. Domínguez Casa, 1993: 222.

10 Robledo Estaire, 2000: 303-304.

11 Ibidem, 2001: 195-206.

12 Constituciones de la Real Capilla, Buen Retiro, 18 de marzo de 1749, AGP, Reinados. Fernando VI, caja 94/5 y Administrativa, 1132 y 1133. 
Mayor va a ser desde ahora también el Limosnero Mayor, por lo que adquiere un mayor protagonismo en la institución, reforzando con ello las competencias que tenía asignadas desde su creación en el ámbito espiritual y eclesiástico, porque en el administrativo la Capilla Real dependía del Mayordomo Mayor de Palacio, que era el jefe de las Casas Reales. Entre las obligaciones asignadas al Capellán Mayor estaba la de hacer cumplir las constituciones de la Capilla, la de ejercer el control absoluto de la misma, asesorado por los capellanes de honor, en quienes recaían los principales empleos (Juez, Fiscal, Cura, Receptor y Maestro de Ceremonias), y la de llevar a cabo el proceso de selección de los aspirantes a una plaza de capellán de honor, de capellán de altar y de predicador real, entre otras.

Las Constituciones de Felipe IV establecían asimismo que el número de capellanes de honor no debía exceder de setenta y dos, correspondiendo cuarenta a la Corona de Castilla ${ }^{13}$, seis a la Corona de Aragón, doce a los originarios de los reinos de Italia y catorce a religiosos de las Ordenes Militares: cuatro por Santiago, tres por Alcántara, tres por Calatrava, dos por Montesa y otros dos por San Juan ${ }^{14}$ Entre 1666 y 1700 consiguieron plaza ciento ochenta y un capellanes de honor, aunque el incremento mayor tuvo lugar en 1677 como consecuencia de crearse una Capilla Real para la reina madre durante su destierro en Toledo. Respecto a los predicadores reales, las Constituciones de 1623 tan solo establecían la obligatoriedad de que un predicador perteneciera a las filas del banco de capellanes, reservando al monarca la designación de cuantos predicadores desease nombrar procedentes de las órdenes religiosas ${ }^{15}$, pero hacia 1653 la nómina quedó establecida en treinta y nueve predicadores, de los cuales sólo catorce cobraban gajes por la Casa de Castilla $^{16}$. Entre 1621 y 1665 Felipe IV nombró ciento cincuenta predicadores, en su mayoría ad honorem, y esta tendencia continuará en el reinado de Carlos II: trescientos cincuenta y dos individuos fueron designados para el empleo entre 1666-1700, lo que demuestra la necesidad de la corona de atraer a su órbita a un colectivo afín a sus intereses y sin coste alguno para la Hacienda Real, pues con ello se granjeaba el apoyo de las oligarquías locales de cuyas filas procedían en buena medida los predicadores reales y también los capellanes de honor. Con todo, los capellanes de honor nacidos en América

13 En ella se integraban los territorios castellanos peninsulares y sus conquistas (América, Navarra y las Islas Canarias) así como las Provincias Vascas y los Países Bajos españoles.

14 De las Constituciones de la Capilla Real, 1623, AGP, Real Capilla, caja 72/1 y Constituciones, 21 a 25

15 De las Constituciones..., 1623, AGP, Real Capilla, caja 72/1 y Constitución, 15.

16 Negredo del Cerro, 2006: 52-59. 
apenas ascendieron a siete y los predicadores reales a diecisiete. A partir de 1677 se procuró congelar la plantilla y evitar la entrada de nuevos capellanes a pesar de su progresivo envejecimiento y de las vacantes causadas por muerte o promoción de los capellanes ${ }^{17}$. Esta revisión afectó de manera drástica a los predicadores reales, cuyo número fue reducido a tres por cada orden religiosa entre numerarios y supernumerarios, aunque no se vieron perjudicados los criollos por hallarse en su mayoría restablecidos a sus lugares de origen. Sin embargo, la caída en desgracia del duque de Medinaceli modificará este panorama, ya que la renovación de las camarillas palatinas y la influencia cada vez mayor de Mariana de Neoburgo, segunda esposa de Carlos II, originó una última oleada de nombramientos de capellanes de honor y de predicadores reales entre 1686 y 1690, circunstancia que no se repetirá ni siquiera durante la Guerra de Sucesión a raíz de la desafección a Felipe V de varios criados de su Capilla ${ }^{18}$.

Gráfico I. Nombramiento de CAPEllanes de honor y de PREDicadores REALES CRIOLlos Bajo CARLOS II

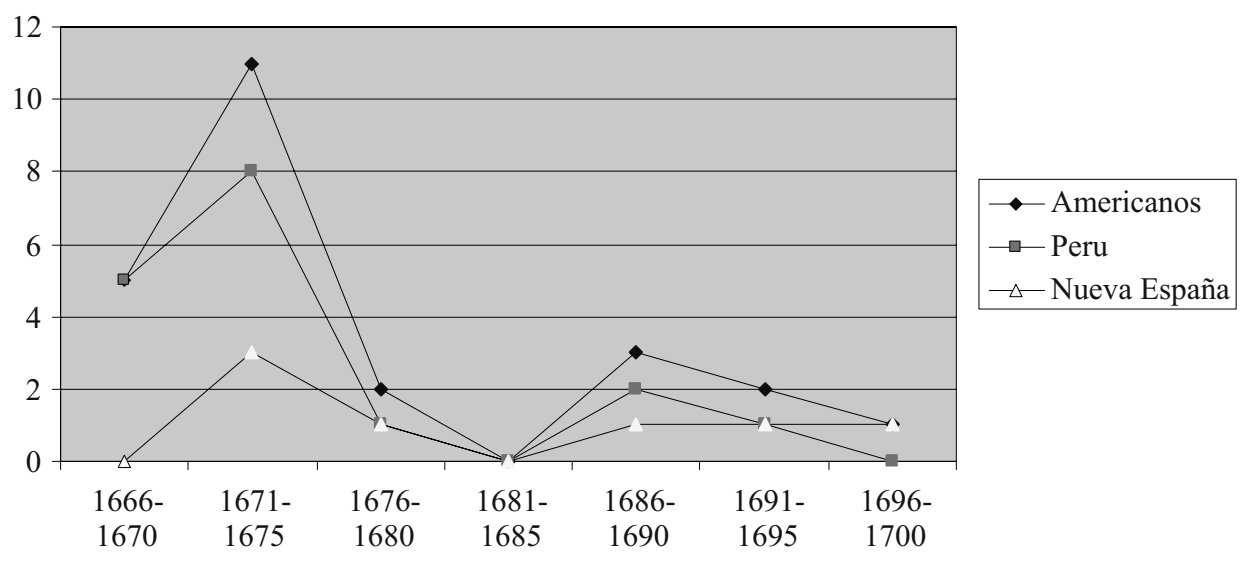

Fuente: elaboración propia.

17 En 1677 sólo estaban ocupadas cuarenta y cinco plazas de capellanes de honor correspondiendo veinticuatro a la corona de Castilla, once a las Órdenes Militares, siete a los reinos de Italia y tres a la corona de Aragón (Consulta del Patriarca, 18 de agosto de 1677, AGP, Real Capilla, caja 70/1).

18 Sánchez Belén, 2001: 417-423. 
Acceder a una capellanía de honor o a una plaza de predicador real implicaba que los candidatos debían demostrar que poseían una buena formación intelectual, con estudios superiores, según defendiera fray Agustín Salucio a finales del siglo XVII ${ }^{19}$, y que habían ejercido la enseñanza y desempeñado cargos de responsabilidad, bien en sus respectivas órdenes, bien en la Iglesia secular; en el caso de los predicadores, debían también contar en su haber con buenas dotes para la oratoria y la teatralidad ${ }^{20}$. Empero, los méritos personales, aun cuando en ocasiones fueran reforzados con los del linaje al servicio de la Monarquía, no bastaban para ingresar en la Capilla Real, ya que las Constituciones exigían a los pretendientes ser de noble y limpio linaje, es decir, que debían pertenecer, si no a las familias más linajudas de su tiempo, sí a familias hidalgas o que estaban en posesión de ejecutoria de hidalguía, sin mácula alguna de judaizantes ni de herejes, que dispusieran de unos ingresos sustanciales con los que mantenerse y que contasen con amistades o parientes influyentes, pues a menudo su ingreso en la Capilla Real venía auspiciado por personajes relevantes de la Corte o de la Iglesia. Por eso, en el proceso para acceder a una plaza de capellán de honor o de predicador lo que verdaderamente importaba era que los candidatos propuestos por el monarca lograran superar unas pruebas de nobleza y limpieza de sangre, para lo cual se designaba a uno o varios capellanes de honor para que recabaran información sobre sus ascendientes hasta la tercera generación, debiéndose desplazar a los lugares de origen del aspirante, salvo en el caso de los nacidos fuera de España, pues entonces las averiguaciones se realizaban en Madrid. Los informantes, si todo se había desarrollado conforme a derecho, elaboraban un informe final favorable, el cual debía ser ratificado por una comisión presidida por el Capellán Mayor, quien posteriormente avisaba al Mayordomo Mayor para que procediera a registrase el nombramiento oficial a fin de que el interesado pudiera realizar el juramento, a partir del cual empezaba a ejercer sus funciones y a correr el plazo para el cobro de sus emolumentos.

El ingreso en la Capilla Real de Palacio, aun siendo a título honorífico, resultaba una aspiración digna de ser considerada para muchos eclesiásticos, fueran seculares o regulares, ya que les facilitaba introducirse en el centro mismo del poder de donde emanaba la gracia real, decisiva para obtener nuevos empleos de mayor relieve, eclesiásticos o civiles (canonjías, deanatos, obispados o virreinatos) en beneficio propio o de la orden religiosa a la que

19 «Grande temeridad sería subirse al púlpito sin haber, y muy bien, estudiado» (Citado por Herrero Salgado, 1998: 86).

20 De la teatralidad en la oratoria sagrada se han ocupado, entre otros, Egido, 2001: 87110; Robledo Estaire, 2002: 154-164 y Rodríguez de la Flor, 1999: 307-346. 
pertenecían, cuando no de sus familiares y allegados o de la cada vez más identificada comunidad criolla de la que procedían ${ }^{21}$. Como expone Diego de Baños y Sotomayor en un Memorial de 1668, la plaza de predicador real que solicita, además de recompensar sus méritos y servicios a la Corona, contribuirá a honrar de manera muy especial a sus compatriotas, «a todos los de aquellos reinos, por no hallarse hoy en ellos ninguno que obtenga este título siendo tan humildes vasallos de V.M ${ }^{22}$. Lo de menos, en cualquier caso, era el salario, ya que su cuantía no estaba a la altura del rango social que hacía atractivos estos empleos. Pues si los predicadores reales percibían 60.000 maravedíes al año, no siempre retribuidos puntualmente ${ }^{23}$, los capellanes de honor, con la salvedad de quienes ocupaban los empleos de receptor, juez, fiscal, cura de palacio, maestro de ceremonias y teniente de limosnero, carecían en el siglo XVII de retribuciones fijas por sus tareas en la Capilla Real, recibiendo únicamente en concepto de distribuciones por asistir a las celebraciones religiosas (40 horas al mes) unos emolumentos casi simbólicos e insuficientes para cubrir sus necesidades, por más que se beneficiasen de otras prebendas, como el disfrute de casa de aposento ${ }^{24}$. No obstante, la mayoría de los capellanes de honor, como titulares de curatos y de canonjías, disfrutaban de prebendas eclesiásticas con las que vivir dignamente, sin mencionar las rentas devengadas de sus respectivos patrimonios personales.

Por otro lado, los capellanes de honor y predicadores reales que no servían en la Capilla Real fueron excluidos del reparto de distribuciones y de salarios al no ejercer sus empleos en Palacio, lo cual afectó sobre todo a los de origen criollo, a quienes se denegó semejante merced, como también la concesión de los gajes vacantes de predicador: así sucedió en 1672 a petición de fray Cipriano de Herrera y en 1695 a instancias de fray José Bernardo de Quirós ${ }^{25}$. Tal decisión resultó muy perjudicial a los intereses de este grupo social, máxime cuando sus ingresos, en el caso de los capellanes de honor, procedían de

21 Santa Eugenia, 2004: 77-92. Alejos Grau, 2001: 285-310. Mantilla, 1996: 121-138. Para el siglo XVIII, González Acosta, 2000.

22 Memorial de Diego de Baños y Sotomayor, 1668, AGP, Expedientes Personales, caja $7730 / 3$.

23 Consulta del Patriarca, 18 de agosto de 1677, AGP, Real Capilla, caja 70/1. Sánchez Belén, 2001: 411-447.

${ }^{24}$ Disfrutaban además de asistencia sanitaria y de medicinas dispensadas por la Real Botica. Finalmente, otros capellanes de honor obtenían ingresos adicionales por asistir a los reyes en sus viajes (Saavedra Zapater, 2005: 142).

25 Consulta del Patriarca, 12 de enero de 1672, AGP, Expedientes Personales, caja 7732/1. Consulta del Patriarca, 14 de julio de 1694, AGP, Expedientes Personales, caja $7755 / 1$. 
las rentas que gozaban en sus lugares de residencia y no resultaba fácil ni barato remitir su importe desde América a España, si bien todo dependía, en última instancia, de sus contactos, pues se tiene información de poderes notariales escriturados en Madrid por algunos de estos capellanes de honor para que sus apoderados les enviaran dinero en efectivo o en letras ${ }^{26}$. Peor les fue todavía a los predicadores reales supernumerarios porque carecían de ingresos propios, lo que suponía que su mantenimiento estaba a cargo de la orden a la que pertenecían y de los conventos que los acogían en Madrid, los cuales, sin embargo, no se beneficiaban del honor de alojar a un predicador real, pues tal mérito recaía en el convento de donde procedía, aparte de que su integración en la comunidad que lo recibía no siempre fue efectiva. Precisamente por eso, y pese a las reticencias en concederse este tipo de mercedes, el 27 de mayo de 1699 el Patriarca asigna a fray Miguel de Lima los gajes de predicador que habían quedado vacantes por promoción de fray Francisco de Paula, de la Orden de los Mínimos, al obispado de Barbastro, pues el beneficio «recae en toda la comunidad de la casa donde habita» ${ }^{27}$.

Así pues, la honra personal, la familiar, la de la comunidad religiosa en la que habían ingresado o la de la nación a la que pertenecían primaba en los aspirantes a un empleo en la Capilla Real sobre cualquier otra consideración, minimizando, por ejemplo, los elevados costes que conllevaba el nombramiento de capellán de honor o de predicador real: gastos por las pruebas, por las certificaciones de los documentos que se les exigían para demostrar su filiación, sus estudios y los cargos que habían desempeñado, y gastos de los salarios de los procuradores o representantes legales que habían nombrado en la corte para realizar los trámites oportunos. Solo las pruebas de nobleza y limpieza de sangre suponían para los aspirantes un importante desembolso, pues los jueces comisionados a tal efecto tenían asignado un salario de cuatro ducados al día en las Constituciones de 1623 -seis ducados a comienzos del siglo XVIII-, y no eran los únicos en ser retribuidos, ya que también se abonaba un salario adecuado a los escribanos que les asistían, si bien el importe total que unos y otros percibían dependía del tiempo empleado en realizarse las pesquisas, por lo general situado en torno a catorce días ${ }^{28}$. No era éste,

26 Bernardo Zamudio de las Infantas, por ejemplo, percibe en Madrid los gajes que tenía asignados como chantre de la iglesia metropolitana de Lima a través de intermediarios (Carta de poder para cobros, 24 de marzo de 1687, Archivo Histórico de Protocolos de Madrid (AHPM), 11540, folios 220 y 368). $7749 / 4$.

27 Consulta del Patriarca, 27 de mayo de 1699, AGP, Expedientes Personales, caja

28 A esos salarios hay que sumar una cantidad de dinero que se entregaba al secretario del Patriarca en concepto de propinas para su familia y derechos de la secretaría (Saavedra 
empero, el único gasto que debían afrontar los aspirantes a una de estas plazas, ya que muchos tuvieron que recurrir a los servicios de apoderados para facilitar la tramitación de sus expedientes. En este sentido sabemos que José de Arechederra había designado como su procurador a Diego Ignacio de Córdoba con el encargo de entregar durante su ausencia de Madrid la documentación que se le pidiere, y lo mismo harían fray Dionisio Negrón de Luna -su procurador será el futuro predicador real fray Jerónimo de Colina- y José de Baños y Sotomayor, canónigo de Guatemala, quien el 15 de junio de 1670 otorgó un poder al licenciado Lorenzo Liceras para que solicitara en su nombre dignidades eclesiásticas -es interesante mencionar que este personaje había intervenido como testigo en las pruebas para predicador de fray José de Urrutia ${ }^{29}$. Por su parte, fray Ignacio de la Cerda, cuando se desplaza a Roma por asuntos relacionados con su orden, designa a José de Saavedra Bustamante, caballero de Santiago, como su apoderado en Madrid -éste personaje había sido o seguía siendo gobernador de Loja, en Perú, y será residenciado en $1683^{30}$ - para presentar, cuando le fueren solicitados, diferentes documentos suyos, entre ellos su genealogía y la fe de bautismo, aunque a la hora de entregar esta última argumentará que no la encuentra, pero que por ella sabe dónde fue bautizado y quienes fueron sus padres ${ }^{31}$.

\section{ORÍGENES GEOGRÁFICOS Y SOCIALES DE LOS CAPELLANES DE HONOR Y DE LOS PREDICADORES REALES CRIOLLOS}

La presencia de capellanes de honor y de predicadores reales nacidos en América en la Capilla Real de Palacio superaba a finales del siglo XVII a la representación de flamencos y navarros, se aproximaba a la que tenían los oriundos de los reinos italianos y de la Corona de Aragón, pero era casi insignificante, como las anteriores, si se la comparaba con la que gozaban los naturales de los reinos peninsulares de la Corona de Castilla.

Esta desigual participación de los súbditos de la Monarquía Hispánica, que refleja el predominio cada vez más evidente de las elites castellanas en su administración y gobierno, en modo alguno debe ocultar ni enmascarar el interés de los criollos en obtener estos empleos, es decir, el de las familias

\footnotetext{
Zapater, 2005: 108).

29 Poder de José de Baños y Sotomayor, 15 de junio de 1670, AHPM, 11.516, fol. 181.

30 Saavedra Zapater, 2009: 1230. Herzog, 2004: 161-183.

31 Expediente de fray Ignacio de la Cerda, 1673, AGP, Expedientes Personales, caja $7738 / 9$.
} 
CuAdro I. Distribución DE los CAPELlanes DE HONOR Y PREDICADORES REALES POR CORONAS (1666-1700)

\begin{tabular}{|l|c|c|c|c|}
\hline \multicolumn{1}{|c|}{ Naturaleza } & Predicadores & $\begin{array}{c}\text { Capellanes } \\
\text { de honor }\end{array}$ & Total & Porcentaje \\
\hline Reinos Corona de Aragón & 20 & 15 & 35 & 6,1 \\
\hline Reinos de Italia & 10 & 13 & 23 & 4,3 \\
\hline Reino de Navarra & 9 & 4 & 13 & 2,4 \\
\hline Reinos de América & 17 & 7 & 24 & 4,5 \\
\hline Territorios de los Países Bajos & 2 & 5 & 7 & 1,3 \\
\hline Reinos de Castilla & 293 & 137 & 430 & 81,3 \\
\hline Total & 352 & 181 & 533 & 100 \\
\hline
\end{tabular}

Fuente: Elaboración propia.

que se habían establecido en América hacia ya varias generaciones, algunas de las cuales remontaban sus orígenes a los primeros tiempos de la conquis$\mathrm{ta}^{32}$, sobre todo de las asentadas en el virreinato del Perú. Pues de la información obtenida se desprende que los individuos originarios de dicho virreinato ponían un mayor énfasis en conseguir estos honores que los de Nueva España (Cuadro II), fenómeno que se aprecia también en las filas de la nobleza titulada y en los empleos públicos de las Audiencias ${ }^{33}$, lo que tal vez obedezca a la vitalidad de la sociedad novohispana, menos dependiente de la metrópoli para su desarrollo económico que la del virreinato de Perú ${ }^{34}$.

Es interesante subrayar, por otro lado, que fueron pocas las familias de estos eclesiásticos que hubieran residido en América más de dos generaciones: seis de un total de veinticuatro, lo que representa un 25 por ciento. Además, este grupo estaba muy arraigado en las localidades donde se establecieron (Arequipa, México, Santiago de Chile, Ica y Lima) con la salvedad de la familia de fray Ignacio de la Cerda, pues si él había nacido en Santiago de Chile, su padre, Cristóbal de la Cerda Sotomayor, había visto la luz en México, al igual que sus progenitores, en tanto que su madre, Sebastiana de Avendaño, lo había hecho en Lima, de donde también eran naturales los

32 Así lo afirmaba fray Ramón de Morales, natural de Santiago de Chile, y lo aseguraban los testigos en las pruebas del mexicano fray Agustín Sarralde (AGP, Expedientes Personales, cajas $7738 / 6$ y $7942 / 1)$.

33 Maruri Villanueva, 2009: 207-240. Rizo-Patrón, 1990: 129-163. Respecto a este mismo fenómeno, pero en las Audiencias virreinales, Burkholder y Chandler, 1984: 47 y 83.

34 Klein, 1995: 35-61. 
Cuadro II. Nombramientos DE los CAPEllanes DE HONOR Y PREDICADORES REALES POR VIRREINATOS (1666-1700)

\begin{tabular}{|c|c|c|c|c|c|}
\hline Años & Nombramientos & $\begin{array}{c}\text { Virreinato } \\
\text { del Perú }\end{array}$ & $\%$ & $\begin{array}{c}\text { Virreinato } \\
\text { Nueva España }\end{array}$ & $\%$ \\
\hline $1666-1670$ & 5 & 5 & 20,83 & 0 & 0 \\
\hline $1671-1675$ & 11 & 8 & 33,33 & 3 & 12,5 \\
\hline $1676-1680$ & 2 & 1 & 4,16 & 1 & 4,16 \\
\hline $1681-1685$ & 0 & 0 & 0 & 0 & 0 \\
\hline $1686-1690$ & 3 & 2 & 8,33 & 1 & 4,16 \\
\hline $1691-1695$ & 2 & 1 & 4,16 & 1 & 4,16 \\
\hline $1696-1700$ & 1 & 0 & 0 & 1 & 4,16 \\
\hline Total & 24 & 17 & 70,83 & 7 & 29,16 \\
\hline
\end{tabular}

Fuente: Elaboración propia.

abuelos maternos del predicador ${ }^{35}$. Muy próximo a este grupo, aunque se ha contabilizado aparte, estarían las familias de los mexicanos José de Adame y Arriaga y fray Jerónimo de Colina pues sus respectivos padres habían nacido en América, así como las abuelas paterna y materna del primero y los abuelos maternos del segundo ${ }^{36}$. En cambio, sólo se ha localizado una familia en la que los padres eran naturales de América pero no así los abuelos: se trata de la de Luis de Orellana y Luna, hermano de María Josefa de Orellana y Luna, marquesa de Corpa $^{37}$.

Lo frecuente, sin embargo, fue que la rama materna llevase varias generaciones instalada en América, mientras que la paterna procediese de España o de otros territorios de la Monarquía Católica como consecuencia de haber emigrado recientemente el padre a las colonias para adquirir fortuna, cuando no por necesidades de servicio al rey. Este fenómeno se aprecia en los orígenes familiares del 33,3 por ciento del total de los capellanes de honor y predicadores reales americanos. A modo de ejemplo se puede mencionar la familia de Bernardo Zamudio y de las Infantas, ya que la abuela materna, Ana de Villegas y Montoya, había nacido en Lima, al igual que la madre, María de las Infantas, mientras que el abuelo materno era oriundo de Córdoba y los abuelos paternos de Sevilla, localidad en la que también había nacido el pa-

35 Pruebas de limpieza del linaje, 1668, 1671, 1673 y 1694, AGP, Expedientes Personales, cajas 7735/11, 7738/6, 7738/7, 7738/9, 7755/1 y 7942/1. Véase también el Expediente de información de fray José de Urrutia en AHN, Inquisición, leg. 1280, exp. 96.

36 Ibidem, 1674 y 1691, AGP, Expedientes Personales, cajas 7946/8 y 7962/1.

37 Ibidem, 1672, AGP, Expedientes Personales, caja 7737/7. 
dre $^{38}$. Pero no siempre la familia era originaria de España o de América: los antepasados paternos de Agustín y fray Dionisio Negrón y Luna procedían de Calvi (Córcega) y los de fray Cipriano de Herrera de Milán ${ }^{39}$. A su vez, el origen familiar de José de Adame y Arriaga se remonta a la ciudad de Besançon, de donde era natural Andrés, el jefe de la dinastía, quien se había afincado en España, concretamente en Frejenal de la Sierra, a comienzos del siglo XVI, si bien los padres y las abuelas materna y paterna habían nacido en México, en tanto que el abuelo paterno había visto la luz en Umbrete, en el Aljarafe sevillano, y el materno en Arriaga, en Vizcaya ${ }^{40}$.

Por último, a la primera generación de emigrantes pertenece el 25 por ciento del total de capellanes de honor y predicadores reales analizado: fray Benardino de Quiñones y Cerón, Tomás Melgarejo Ponce de León, Antonio Prieto y los hermanos Diego y José de Baños Sotomayor ${ }^{41}$. En el caso de fray Miguel de Lima, en el mundo Tomás de Santiago Concha, la familia paterna procedía del lugar de Heras, en la diócesis de Burgos, y la materna de Medina Sidonia, lugar de nacimiento del abuelo, y de Villaseca de la Sagra, donde había nacido la abuela. El padre, Pedro de Santiago Concha, se había trasladado a Perú, donde sería Proveedor General del Mar del Sur, mientras que la rama materna lo había hecho bastantes años antes, ya que uno de los bisabuelos maternos, Gaspar Fernández, familiar del Santo Oficio, había emigrado a Indias con toda su familia, y el abuelo materno, Benito Méndez de Salvatierra, también, puesto que en Lima nace su hija Mayor Méndez Salvatierra, madre de nuestro predicador ${ }^{42}$.

Pocas pruebas consistentes se disponen acerca de la nobleza y limpieza de sangre de las familias de los capellanes de honor y predicadores reales americanos, ya que su establecimiento en al continente americano supone una gran dificultad a la hora de precisar la ortodoxia religiosa y el origen nobiliario de sus miembros, sobre todo cuando, para reducir costes, se omite realizar el interrogatorio de testigos en los lugares de nacimiento y residencia de los padres y abuelos. Esto va a tener consecuencias importantes para sus linajes, ya que los testimonios recogidos en Madrid aportan, en la mayoría de los

38 Ibidem, 1687, AGP, Expedientes Personales, caja 7811/4. Lohmann Villena, 1983, vol. II: 337 .

39 Ibidem, 1668 y 1674, AGP, Expedientes Personales, cajas 7732/1, 7805/6, 7739/11. Para fray Cipriano de Herrera se puede consultar las pruebas que se le hacen para comisario del Santo Oficio (AHN, Inquisición, leg. 1213, exp. 18).

40 Ibidem, 1691, AGP, Expedientes Personales, caja 7962/1.

${ }^{41}$ Ibidem, 1668, 1669, 1673, 1675, 1680, 1688, AGP, Expedientes Personales, cajas 7730/3, 7734/1, 7740/8, 7749/4, 7809/14, 7941/30.

42 Ibidem, 1688, AGP, Expedientes Personales, caja 7749/4. 
Cuadro III. Procedencia geográfica de los antepasados DE LOS CAPELLANES DE HONOR Y PREDICADORES REALES AMERICANOS (1666-1700)

\begin{tabular}{|l|c|c|}
\hline \multicolumn{1}{|c|}{ Orígenes de la familia } & Individuos & \% \\
\hline Padres y abuelos españoles & 6 & 25 \\
\hline Madre americana & 1 & 4,2 \\
\hline Madre y abuelos maternos americanos & 8 & 33,3 \\
\hline Padres americanos & 1 & 4,2 \\
\hline Padres y abuelos maternos americanos & 2 & 8,3 \\
\hline Padres y abuelos americanos & 6 & 25 \\
\hline Total & 24 & 100 \\
\hline
\end{tabular}

Fuente: Elaboración propia.

casos, noticias vagas e imprecisas sobre el origen, limpieza y nobleza de sangre de los aspirantes a estas plazas, aun cuando coinciden en un punto al afirmar que proceden de familias cristiano-viejas, quizás porque lo eran o porque habían conseguido ocultar sus orígenes conversos gracias a una acertada política matrimonial y a la obtención de empleos en la Iglesia y en los tribunales del Santo Oficio de la Inquisición. Así, José de Arechederra podía vanagloriarse de que un tío abuelo hubiera sido Comisario del Santo Oficio, y fray Jerónimo de Colina de que un hermano de su madre hubiera llegado a ser fiscal del Santo Oficio de México, pero más méritos tenían los hermanos Diego y José de Baños y Sotomayor, pues su padre había sido consultor del Santo Oficio y su abuelo materno familiar de dicho Tribunal. En esta línea es interesante mencionar que los Adame, aparte de poseer expediente de limpieza de sangre desde 1566, estaban reputados «de gente muy honrada e rica e cristianos viejos conocidos», y de haberse enfrentado con denuedo a «los confesos cristianos nuevos que entonces había en Frejenal, e trataron muy grandes e recios pleitos con ellos para que no entrasen en cabildo, y así es público y notorio» ${ }^{43}$.

La mayoría alegaba además unos orígenes hidalgos por proceder de determinadas regiones donde sus habitantes gozaban de esta consideración -lo hace José de Arechederra, cuya hidalguía procedía del padre por ser oriundo del País Vasco- o por estar sus familias exentas de contribuciones pecheras y en posesión de carta ejecutoria de nobleza obtenida por una sentencia firme de las Chancillerías de Valladolid o de Granada, como Tomás Melgarejo Ponce

43 Ibidem, 1691, AGP, Expedientes Personales, caja 7962/1. 
de León, a pesar de que su abuelo materno fuera el arquitecto Juan Gómez de Mora. En ocasiones, para reforzar su criollismo y su nobleza se mencionan antepasados que habían destacado en la conquista de América: es el caso de los Adame, ya que un tal Rodrigo Adame, natural de Frejenal de la Sierra, fue uno de los primeros conquistadores que pasaron a América con el capitán Pedrarias Davila, falleciendo «en las islas de Panamá». Pero aunque no siempre se presentan documentos fehacientes que confirmen la nobleza de los candidatos, el nivel de vida de sus familias y la opinión que sobre sus linajes tenían los contemporáneos bastaban para acreditarlos como tales nobles. Sucede así con fray Nicolás Hurtado de Ulloa, ya que algunos testigos no dudan en afirmar que la familia era de hidalguía conocida, «y en tal posesión habidos, y se hallan por una y otra línea condecorados con muchos actos de la Inquisición y hábitos de Santiago, que han tenido parientes del dicho pretendiente muy cercanos, así de los naturales de la ciudad de Toledo como de los de la de Lima, y en unas y otras partes son tan conocidas estas familias que hacen mucha estimación de ellas y son de las primeras de quien echan mano para los oficios que en dichas ciudades tienen [...], sin que en jamás ni en tiempo alguno haya oído ni entendido cosa en contrario» ${ }^{44}$. Por eso, se puede afirmar entonces que estamos ante un grupo social integrado en la ortodoxia religiosa y en pleno proceso de ascenso social, cuando no pertenecían sus miembros a la rama segunda de un linaje ya ennoblecido y en posesión de título nobiliario, como los Bernaldo de Quirós. Lo confirma las profesiones de los abuelos, padres, hermanos, tíos y sobrinos, pues por lo general viven de lo que producen sus haciendas y ejercen empleos públicos en los concejos (los Negrón, según los testigos, han ocupado «los puestos más honoríficos en la ciudad de Lima»), en el ejército y en la administración de justicia, sobre todo en las Audiencias, como fiscales y oidores ${ }^{45}$, un puesto éste de indudable estima por el trato respetuoso que se debe dar a sus titulares en razón del lugar privilegiado que ocupaban en el orden social, motivo de codicia para muchos al margen de los beneficios económicos que podían obtener ${ }^{46}$.

44 Ibidem, 1672, AGP, Expedientes Personales, caja 7737/10. Véase también las informaciones que se le realizan por el Santo Oficio en AHN, Inquisición, leg. 1332, exp. 11.

45 Solo se dispone de información sobre los empleos de la familia de 17 capellanes de honor y predicadores reales, lo que representa el 68\% del total analizado. De este conjunto, los principales empleos están relacionados con la administración de la justicia (oidores, corregidores, gobernadores y alcaldes), el gobierno municipal (regidores) y la milicia (capitanes y maestres de campo), aunque también se localizan eclesiásticos, sobre todo entre los hermanos y los tíos de los capellanes de honor y predicadores.

46 Bridikhina, 2007: 565. Puente Brunke, 2006: 133-148. 


\section{Parentesco, patronazGo y SOlidaridades REgionales}

La información sobre los orígenes geográficos y sociales de los capellanes de honor y de los predicadores reales, así como sobre las profesiones de sus familiares, permiten fijar y analizar la compleja maraña de alianzas sociales que tejen en torno suyo y para lo cual movilizan todos los recursos disponibles a su alcance como la parentela, la nacionalidad, el paisanaje, la amistad y el patronazgo, aparte de la reputación propia -y la de familiares y allegadosobtenida a través de los empleos y de los servicios a la Corona, que siempre se esgrimieron para reforzar su posición. De este modo se comprende que la entrada de un sujeto en alguna de las dependencias de las Casas Reales propiciase la incorporación de otros individuos de su misma estirpe e incluso de su propio círculo social. Agustín Negrón y Luna, capellán de honor en 1668, facilita el camino a su hermano fray Dionisio Negrón y Luna, ya que en 1675 es nombrado predicador real. Lo mismo hace el también capellán de honor Diego de Baños y Sotomayor: en 1668 toma posesión del cargo y en 1673 lo hace su hermano José como predicador real. Por su parte, Juan Ignacio de Castorena y Urzúa debe su nombramiento y su posterior carrera eclesiástica a los Goyeneche, ya que uno de sus bisabuelos paternos era Martín de Goyeneche, abuelo del tesorero real Juan de Goyeneche ${ }^{47}$, mientras que fray Nicolás de Orellana y Luna, predicador real en 1675, puede que obtuviera el empleo a instancias de su cuñado Luis Ibáñez de Segovia y Peralta, marqués de Corpa, hermano del marqués de Mondejar. Lo propio cabe decir de fray José Bernaldo de Quirós, emparentado con Gabriel Bernaldo de Quirós, I marqués de Monreal ${ }^{48}$.

Asimismo, en el acceso de los eclesiásticos criollos a la Capilla Real en las décadas finales del siglo XVII jugaron un papel importante las solidaridades regionales contribuyendo a su vez a entretejer al otro lado del Atlántico una compleja red identitaria superpuesta incluso a sus particulares intereses. Sólo así se explica que entre los testigos de los candidatos figuren varios personajes procedentes de sus lugares de nacimiento o de las ciudades en las que habían estudiado y ocupado cargos, pero también familiares de otros eclesiásticos que ya habían obtenido -o que obtendrían- los empleos de capellán de honor o de predicador real, lo que asimismo se aprecia en las pruebas para caballeros de hábito de pretendientes americanos ${ }^{49}$. En este sentido,

47 Caro Baroja, 1969: 83.

48 Pruebas de limpieza del linaje, 1675 y 1694, AGP, Expedientes Personales, cajas 7737/7 y $7755 / 1$.

49 Lohman Villena, 1947. 
la comunidad originaria del virreinato del Perú, sobre todo la limeña, se muestra muy solidaria a la hora de apoyar a sus naturales. Los datos son contundentes: Pedro Carlos Negrón y Luna, capellán mayor del convento de monjas de las Maravillas de Madrid, hermano de los ya citados Agustín y fray Dionisio Negrón y Luna, interviene en 1668 en las pruebas de fray Ignacio de la Cerda y de fray José de Urrutia y Cruz, aspirantes a una plaza en la Capilla Real de Palacio. Este último, a su vez, aparece en las pruebas de fray Dionisio Negrón y Luna, así como en las de fray Ignacio de la Cerda y fray Nicolás de Orellana y Luna. Por su parte, Agustín Negrón y Luna figura como testigo en las pruebas de ingreso de otro criollo, fray Cipriano de Herrera, mientras que en las suyas y en las de fray Ramón de Morales ${ }^{50}$ interviene, también en 1668, Bartolomé de Cifuentes y Guerrero, cura rector de la ciudad de Castrovireira y sus anejos, hermano del predicador real fray Domingo de Cifuentes ${ }^{51}$. Unos años más tarde, en 1672, residían en Madrid, oriundos de Lima, los presbíteros Juan de Castro y Miguel de Medrano Salazar, cura de la iglesia catedral de Lima, quienes testifican en las pruebas de varios predicadores reales, entre ellos fray Diego Serrano ${ }^{52}$.

En cuanto al patronazgo, los datos disponibles son menos numerosos, pero no irrelevantes, pues vienen a demostrar la capacidad de mediación de los virreyes, gobernadores, presidentes y oidores de las Reales Audiencias, así como la de los prelados y cabildos eclesiásticos en la misma Corte. Lo demuestra, por ejemplo, el apoyo que José de Adame y Arriaga obtiene a lo largo de su carrera profesional tanto de los virreyes de Nueva España como del cabildo de la iglesia metropolitana de México, corporación que en 1675 solicita al monarca que le conceda una prebenda por sus virtudes y méritos, lo que reitera en 1684 , cuando ya era canónigo ${ }^{53}$. Con los mismos asideros se sostendrán el también mexicano fray Agustín de Sarralde, predicador real

50 Morales intervendrá en 1672 y 1673 en las pruebas de fray Nicolás de Orellana y Luna y de fray Ignacio de la Cerda (AGP, Expedientes Personales, cajas 7737/7 y 7738/9).

51 Véanse las Pruebas de limpieza de sus linajes (AGP, Expedientes Personales, cajas, 7732/1, 7737/7, 7738/7, 7738/9, 7739/11, 7813/1, 7942/1 у 7805/6).

52 Ambos aparecen como testigos en el expediente de fray Diego Serrano (AGP, Expedientes Personales, caja 7737/8). El primero testifica además en las pruebas de fray José de Urrutia y Cruz (AGP, Expedientes Personales, caja 7738/7) y el segundo en las de fray Nicolás de Orellana y Luna, fray Ignacio de la Cerda, Agustín Negrón de Luna y fray Nicolás Hurtado de Ulloa (AGP, Expedientes Personales, cajas 7737/7, 7738/9, 7805/6, 7737/10).

53 Carta del virrey de Nueva España al secretario del Consejo de Indias, 4 de febrero de 1678, Archivo General de Indias, Sevilla (AGI), México, 50, N 8. Sarabia Viejo, 1985: 171182. 
en $1673^{54}$, y fray Ramón de Morales, avalado por el conde de Santisteban, virrey del Perú en $1665^{55}$. José de Arechederra dispondrá de referentes en Madrid, pues en sus pruebas participaron como testigos el guarda mayor de la provincia de Venezuela, Alonso de la Torre, así como el aposentador y mayordomo de la reina, Pedro de Porras, antiguo gobernador y capitán general de Santiago de León de Caracas ${ }^{56}$. Sin embargo, el mayor $-\mathrm{y}$ mejor- valedor de los capellanes de honor y predicadores reales americanos será el conde de Lemos, virrey del Perú, ya que es durante su mandato, acaecido entre 1667 y 1672, cuando tiene lugar una avalancha de incorporaciones de criollos procedentes de dicho virreinato en la Capilla Real de Palacio, la cual proseguirá hasta 1675 , fecha en la que regresa su viuda a España, fomentada acaso con la finalidad de atraerse hacia su parcialidad a una buena parte de la elite criolla aprovechando el proceso final de la canonización de Santa Rosa de Lima y coincidiendo con una etapa de graves enfrentamientos entre la Corona y la Audiencia de Lima, a la que no fue ajena la revuelta minera de Izacota o Laicacota ${ }^{57}$. No es casualidad entonces, como se puede apreciar en el Cuadro II, que el 54,16 por ciento de los nombramientos de predicadores reales y de capellanes de honor realizados entre 1666 y 1675 recayese en sujetos oriundos del virreinato del Perú.

\section{El CURSUS HONORUM. LA PROMOCIÓN DE LOS CAPELLANES DE HONOR Y DE LOS PREDICADORES REALES CRIOLLOS EN ESPAÑA Y AMÉRICA}

Tanto los capellanes de honor como los predicadores entraron muy jóvenes en el estado eclesiástico: los primeros en torno a los dieciséis años, en que eran ordenados de menores; los segundos alrededor de los catorce años. A partir de aquí inician los estudios que les van a capacitar para desempeñar los cometidos inherentes a su ministerio. Los datos facilitados por los expedientes de ingreso en la Capilla Real y diversos memoriales demuestran que, aun cuando no se dispone de información sobre varios predicadores reales, todos cursaron estudios superiores de Teología y de Derecho, pues, como expone el Patriarca en una consulta al monarca de 21 de septiembre de 1691, la norma es que los sujetos que deben ocupar este empleo sean «los oradores más dig-

\footnotetext{
54 Pruebas de limpieza del linaje, 1673, AGP, Expedientes Personales, caja 7738/6.

55 Carta del conde de Santisteban, virrey del Perú, 18 de noviembre de 1665, AGP, Expedientes Personales, caja 7942/1.

56 Pruebas de limpieza del linaje, 1676, AGP, Expedientes Personales, caja 7808/13.

57 Basandre, 1945. Lohman Villena, 1946. Vargas Ugarte, 1965.
} 
nos y condecorados con becas de colegiales mayores, y obtenido cátedras y prebendas de oficio en iglesia» ${ }^{58}$. Su formación académica sería muy similar a la de los mercedarios fray José de Urrutia y Cruz y fray Diego Serrano, que se graduaron el 21 de noviembre de 1670, respectivamente, de licenciado y doctor en Teología por la Universidad de Ávila, o a la del dominico fray Dionisio Negrón y Luna, que obtuvo en la citada Universidad los grados de bachiller, licenciado y doctor en Teología en 1675, el mismo año en que fue nombrado predicador real ${ }^{59}$. Estos requisitos eran exigidos también para ingresar como capellán de honor, máxime cuando las Constituciones de la Real Capilla establecían que debían ser licenciados o doctores en Teología y Cánones, aunque algunos expedientes no recogen esta información: sucede con Agustín Negrón y Luna, Tomás Melgarejo Ponce de León y José de Arechederra $^{60}$. Por eso, José de Baños y Sotomayor, en el momento de incorporarse a la Capilla Real en 1673, estaba desde el año 1666 en posesión del título de licenciado y doctor en Teología por la Universidad de Ávila, institución en la que también se licenciaron y doctoraron otros compatriotas suyos acaso por las facilidades que ofrecía atendiendo a la premura de sus nombramientos en palacio, algo no previsto al iniciar el viaje a España ${ }^{61}$. Por su parte, José de Adame y Arriaga, pese a su pobreza, y gracias a que sus maestros habían costeado sus estudios, se licencia y doctora en Leyes en la Universidad de México, donde además se había graduado de bachiller en Filosofía y en Teo$\operatorname{logía}^{62}$. Diego de Baños y Sotomayor se doctora en Teología por la Universidad de Santa Fe y en la Universidad de Lima obtienen sus licenciaturas fray Miguel de Lima, fray Cipriano de Herrea y Bernardo Zamudio y de las Infantas: el primero en Cánones y Leyes - posteriormente se licenciará en Artes y Teología en la Universidad de Salamanca-, el segundo en Teología y el tercero en Cánones ${ }^{63}$.

\footnotetext{
$7945 / 5$

59 Herráez Hernández, 1992: 162.

60 Empero, de José de Arechederra se dispone de varios memoriales en los que constan sus estudios (AGI, Indiferente, 121, N 50 y N 60, y 207, N 111).

${ }^{61}$ Se trata de Juan Ignacio Castorena y Urzúa, fray José Bernaldo de Quirós, fray Dionisio Negrón y Luna, fray Diego Serrano y fray José de Urrutia y Cruz. Véase Herráez Hernández, 1992: 157.

62 Certificado del secretario de la Universidad de México y notario de la Inquisición, 14 de julio de 1666, AGI, Indiferente, 126, N 31.

63 La información ha sido obtenida de los Memoriales que envían solicitando una plaza en la Capilla Real (AGP, Expedientes Personales, caja 7732/1, 7749/4, 7811/4).
}

58 Consulta del Patriarca, 21 de septiembre de 1691, AGP, Expedientes Personales, caja 
Pero los estudios no bastaban para acceder a la Capilla Real. Otros requisitos se exigían a los candidatos, entre ellos el haber desempeñado empleos en la Universidad o en la Iglesia. Por desgracia, los expedientes no siempre aportan información al respecto o lo hacen de manera imprecisa, aunque estas lagunas son cubiertas en algunos casos con los datos aportados en escritos dirigidos al Consejo de Indias ${ }^{64}$. En cualquier caso, las noticias apuntan a que su actividad profesional se circunscribió a dos planos: el docente y el eclesiástico. En el terreno académico, fueron lectores y maestros por su religión y catedráticos por oposición. En el campo eclesiástico, los capellanes de honor, dada su condición de clérigos seculares, opositaron y ganaron canonjías (José de Baños y Sotomayor fue canónigo en la catedral de Guatemala, su hermano Diego en la de Santa Fe, después de haber obtenido el curato de dicha iglesia, y Bernardo Zamudio y de las Infantas en la de Lima ${ }^{65}$ ), aparte de ejercer otros empleos, que a menudo simultaneaban, como el de Comisario de la Santa Cruzada. Los predicadores reales a su vez ejercieron diversos cargos de responsabilidad en las órdenes religiosas en las que habían profesado, además de confesar ${ }^{66}$ y de predicar en público en los conventos de sus órdenes, y no sólo en América (fray Miguel de Lima fue predicador en Salamanca, en Valladolid y en el convento capuchino de San Antonio en Madrid ${ }^{67}$ ), dando a la imprenta algunos sermones, como fray Domingo de Cifuentes y José de Baños y Sotomayor ${ }^{68}$. Así, fueron examinadores sinodales, visitadores, guardianes, priores, definidores, calificadores y comisarios del Santo Oficio y provinciales. La trayectoria profesional de fray Cipriano de Herrera antes de su ingreso en la Capilla Real

64 Sucede, por ejemplo, con fray Jerónimo de Colina y José de Arechederra (AGI, Indiferente, 212, N 16 y 207, N 111)

65 Para estos datos consúltense sus Memoriales (AGP, Expedientes Personales, cajas $7941 / 30,7730 / 3$ y $7811 / 4$.

66 Fray Jerónimo de Colina había obtenido licencia para confesar hombres, pero no mujeres, y para absolverlos excepto en los casos de herejía, apostasía y apropiación de los diezmos y demás impuestos pertenecientes a la Iglesia (AGP, Expedientes Personales, caja 7946/8). Otro predicador que consiguió esta licencia fue fray Domingo de Cifuentes (AGP, Expedientes Personales, caja 7735/11).

${ }^{67}$ Memorial de fray. Miguel de Lima, 1688, AGP, Expedientes Personales, caja 7749/4. También predicó en Madrid, en el convento de las Descalzas Reales, el capellán de honor Diego de Baños y Sotomayor (AGP, Expedientes Personales, caja 7730/3).

68 Del primero es Oración panegírica en la festividad de la beatificación de la Virgen Rosa de Santa Maria..., Madrid, Mateo de Espinosa y Arreaga, 1669; del segundo, Sermón de la Bienaventurada Rosa del Perú a la fiesta solemne de su beatificación... Madrid, Mateo de Espinosa y Arteaga, 1670, y Oración panegírica en la fiesta solemne... al arcángel S. Miguel el día de su aparición por el buen sucesso de las armas católicas de España, [s.1., s.n., s.a.]. 
en 1668 resume a la perfección el curriculum vitae de los predicadores reales, ya que para entonces había sido definidor de la Provincia de Perú, calificador del Santo Oficio de Lima, maestro en Artes, catedrático de Prima y de Sagrada Escritura en la Universidad de Lima, prior en varias ocasiones, visitador, secretario y definidor mayor de Lima, y vicario provincial de los arzobispados y obispados de Charcas, Lima, Arequipa, Cuzco y Huamanga, entre otros. Finalmente, en 1670 se encuentra en Roma, donde publica una hagiografía sobre el arzobispo Toribio Alfonso Mogrovejo destinada, con toda probabilidad, a su beatificación ${ }^{69}$. No le sigue a la zaga fray José Bernaldo de Quirós, por más que el Capellán Mayor pareciera desconocer su currículum, según manifiesta en consulta al rey de 16 de marzo de 1694: la relación de méritos del pretendiente «podrá ser cierta, pero no le conozco ni tengo noticia de sus títulos y grados, ni he visto papeles por donde calificarlos, ni más instrumento que su memorial». Semejante desconocimiento del personaje es, cuanto menos, sorprendente, ya que entre 1692 y 1694 había editado en Madrid La Fuente del Paraíso (1694) y Devocionario y compendio de la vida de San Nicolás el Mágno (1692), que sería reeditada en 1697. En cualquier caso, fray José Bernaldo de Quirós, en su solicitud para ingresar en la Capilla Real, destacaba como méritos el haber sido catedrático de Filosofía y de Prima de Teología durante dieciséis años en la Universidad de San Ildefonso de Lima, aparte de haber desempeñado diferentes cargos: regente de estudios en Cuzco, examinador sinodal, visitador general «de todas las idolatrías», visitador provincial de Arequipa, prior electo de Cochabamba, secretario, visitador y vicario provincial de Quito y Popayán, y definidor general y procurador general de las provincias de Quito y Nuevo Reino de Granada en Madrid y en Roma. Además, destaca que siempre había servido al rey, especialmente «en la defensa de la regalía y patronato de V. M. en Indias, como lo ha logrado en Roma ante la Sagrada Congregación de Cardenales, en que ha manifestado su buen celo y lealtad y conseguido cuanto se podía desear en beneficio de dichas provincias y del Real Patrimonio de V.M. como todo lo califican los alegatos y decretos impresos en Roma presentados en el Real Consejo de Indias» ${ }^{70}$. Y al servicio de Dios y del soberano había destacado también fray Ramón de Morales, pues a los muchos años dedicados a la docencia y a ejercer diferentes empleos en

69 Memorial de fray Cipriano de Herrera, 1668, AGP, Expedientes Personales, caja 7732/1. AHN, Inquisición, legajo 1213, exp. 18. La obra a la que nos referimos lleva por título Mirabilis vita et mirabiliora acta dei vener. servi Toribii Alfonsi Mogrobesii Limani Archipraesulis... Roma, Nicolai Angeli Tinassij, 1670.

70 Memorial de fray José Bernardo de Quirós, 1694, AGP, Expedientes Personales, caja 7755/1. 
su orden hay que sumar su labor evangelizadora, «baptizando por su mano muchos indios de las reducciones que se han hecho, y un cacique a quien obedecen gran número de lanzas, y se baptizó persuadido del fervor de su diligencia», como informa de ello al monarca el cabildo de la ciudad de Santiago de Chile en carta dirigida de 24 de octubre de $1666^{71}$.

El ingreso en la Capilla Real de Palacio facilitará a los capellanes de honor y predicadores reales criollos no sólo consolidar el estatus profesional que habían alcanzado hasta ese instante, sino relanzar sus carreras, equiparándose de este modo a los naturales de España. Es verdad que los predicadores reales procedentes de las órdenes religiosas obtuvieron por lo general esta merced cuando ya tenían una trayectoria profesional reconocida, por lo que su estatus apenas se vio modificado con algunas excepciones. En cambio, los que procedían del clero secular llegaron a alcanzar mejores prebendas a partir de sus nombramientos en la Capilla Real de Palacio como lo demuestra el que de de nueve eclesiásticos seculares, siete fueron promocionados con canonjías y prelacías, mientras que de quince eclesiásticos regulares sólo tres fueron presentados para ocupar una diócesis ${ }^{72}$. A estos casos hay que añadir las trayectorias de Jerónimo de Colina, prior en los conventos de Jalapa (1678) y México (1684), de fray Dionisio Negrón y Luna, secretario de cámara del obispo de Santiago de Chile ${ }^{73}$, y de fray Antonio de Avellaneda, que se consagrará a la evangelización de indios en Coahuila y Nayarit ${ }^{74}$.

Estas promociones, que en general se desarrollan en América tras su regreso de la metrópoli ${ }^{75}$, pueden a primera vista parecer irrelevantes, pero en

71 Memorial de fray Ramón de Morales, 1668 y Carta del conde de Santisteban, virrey de Perú, Lima, 18 de noviembre de 1665, AGP, Expedientes Personales, caja 7942/1.

72 Se trata de Diego de Baños y Sotomayor, obispo de Santa Marta (1677) y de Caracas (1683), Juan Ignacio de Castorena y Urzua, obispo de Yucatán (1729), fray Ignacio de Cifuentes, obispo de Aquila (1687) y fray Nicolás Hurtado de Ulloa, obispo de Tucumán (1679). A estos sujetos habría que añadir José de Adame y Arriaga, propuesto en 1692 para la sede de Manila, que renunció, y fray Diego Serrano, presentado para la diócesis de Concepción en Chile. Los dos primeros ocuparon anteriormente una canonjía como también la obtuvieron José de Arechederra, José de Baños y Sotomayor, Agustín Negrón y Luna y Bernardo Zamudio y de las Infantas.

73 Este nombramiento le involucrará, tal vez a su pesar, en el conflicto que su prelado, fray Bernardo Carrasco Saavedra, mantiene con los oidores Sancho García Salazar y Juan de la Cueva y Lugo, quienes habían intervenido veinte años antes, en 1668, como testigos en las pruebas de ingreso en la Capilla real de su hermano Agustín Negrón y Luna.

${ }^{74}$ Real Cédula, Buen Retiro, 25 de mayo de 1688, AGI, Guadalajara, 231, libro 6, fol. 245r-245v.

75 Aunque los capellanes de honor y predicadores criollos regresaron en su mayoría a América lo cierto es que hubo algunas excepciones: fray Ignacio de la Cerda se traslada al 
términos porcentuales no lo son ya que representan el 85,7 por ciento de los capellanes de honor y el 35 por ciento de los predicadores reales criollos nombrados en estos años. Tal afirmación es corroborada si comparamos estos datos con las promociones de los predicadores reales en el reinado de Felipe $\mathrm{IV}$, pues de ciento cincuenta individuos el 25 por ciento fue propuesto para ocupar una sede episcopal por el monarca ${ }^{76}$. Un ejemplo de las carreras desarrolladas por los criollos después de sus nombramientos en la Capilla Real de Palacio nos lo ofrece Juan Ignacio de Castorena y Urzúa. En 1712 se encuentra en el virreinato de Nueva España sirviendo la canonjía doctoral que gozaba en la Catedral de México, donde edita un sermón de acción de gracias por el triunfo de Felipe V en la batalla de Almansa (Parabién de las letras a las armas), en tanto que en Madrid se publica una edición suya de las obras de sor Juana Inés de la Cruz ${ }^{77}$. Diez años después, en 1722, funda la Gaceta de México, cuyo primer número sale de la imprenta en enero de dicho año, aunque el periódico permanecerá poco tiempo en sus $\operatorname{manos}^{78}$, y el 6 de julio de 1729 es presentado y nombrado obispo de Yucatán, sede en la que residirá hasta su fallecimiento acaecido el 13 de julio de $1733^{79}$, y donde compaginará la labor pastoral con la publicación de tratados místicos ${ }^{80}$.

Diego de Baños y Sotomayor también culmina una brillante trayectoria profesional con altos empleos en la Iglesia, pues si en 1676 era rector del Colegio de Cantores de la Capilla Real de Palacio, el 13 de septiembre de 1677 fue nombrado obispo de Santa Marta - había sido presentado por el Rey el 31 de mayo de 1677-, obteniendo licencia para consagrarse en España el 28 de septiembre de 1677. En 1680 figura en tercer lugar en una terna de la Cámara de Indias para el obispado de Santiago de Chile y en octavo lugar para la coadjutoría de La Paz, pero finalmente es promovido el 15 de febrero de 1683 para la diócesis de Caracas, tras presentarlo el rey el 2 de diciembre de 1682, y donde permanecerá hasta su fallecimiento, promulgando en 1687

virreinato de Nápoles para ocupar la diócesis de Aquila, fray Miguel de Lima permanece en Madrid, donde obtiene en 1699 plaza de predicador de número en la Capilla Real de Palacio, y Tomás Melgarejo Ponce de León se instala en la localidad conquense de San Clemente después de abandonar la corte a causa de la falta de recursos económicos para mantenerse con decencia.

76 Negredo del Cerro, 2006: 73

77 Caro Baroja, 1969: 133. Simón Díaz, 1960-1984, vol. VII: 693-696.

78 Más información en Ochoa Campos, 1944.

79 Casado Arboníes, 1989.

80 Escuela mística de María Santísima, en la mística ciudad de Dios, en las doctrinas, que dictó a la V. M. María de Jesús de Agreda, México, 1731. 
unas Constituciones Sinodales ${ }^{81}$. Por las mismas fechas fray Nicolás Hurtado de Ulloa ve cumplidas sus expectativas profesionales ya que en 1674, dos años después de haber sido nombrado predicador real, es designado comisario general y visitador de la provincia de San Miguel de Quito y en 1677 obispo auxiliar de Lima para, por último, ser promovido en 1679 al obispado de Tucumán, donde fallecerá en 1686. Finalmente, José Adame y Arriaga, que en 1691 obtiene la plaza de predicador real supernumerario como broche a una dilatada carrera ${ }^{82}$, es presentado por el monarca, tras consulta del Consejo de Indias, para la sede metropolitana de Manila en 1692, aunque renunciará a ella, según informa a Madrid el virrey de Nueva España ${ }^{83}$.

\section{Conclusiones}

En las últimas décadas del siglo XVII la Capilla Real de Palacio acoge, como nunca antes, a un nutrido grupo de eclesiásticos procedentes del continente americano, en su mayoría del virreinato del Perú, aunque tampoco faltaron los de Nueva España. Esta avalancha de nombramientos, mayor entre el clero regular, y que se explica por el deseo de la comunidad criolla de alcanzar una fuerte presencia en las instituciones de la Monarquía, incluidas las Casas Reales, para así reforzar sus vínculos con la corona, en un momento decisivo para la consolidación de su identidad como nación, ha permitido establecer, a través del análisis de sus expedientes, varias conclusiones importantes. La primera, que los capellanes de honor y predicadores criollos constituyeron un conjunto homogéneo de individuos tanto por lo que se refiere a sus orígenes sociales como por los empleos que habían ejercido sus familiares en el gobierno de los concejos, en las instituciones de justicia, en el ejército y en la administración del Estado, lo que, por otro lado, explica las redes sociales que lograron tejer en torno a sus personas y familias, o a las que se adscribieron, integrados en una determinada clientela, por el sistema del patronazgo. La segunda, que gozaron de una exquisita formación intelectual, según los planes de estudio de la época, similar a la que pudieran haber adquirido en España, lo que contribuye a explicar los empleos ejercidos en la

81 Constituciones Sinodales del Obispado de Venezuela, y Santiago de León de Caracas... 1687, Caracas, 1848.

82 Aguirre Salvador, 1997: 187. Beristain de Souza, 1883, vol. I: 12

83 Consulta del Virrey de Nueva España, 9 de enero de 1693, Archivo Histórico Nacional, Madrid (AHN), Osuna CT 622, D 39. La propuesta en AGI, Filipinas, 3, N 189, y la terna en AGI, Patronato, 7, N 12, R 3. 
docencia y en tareas relacionadas con la gestión administrativa, así en los cabildos catedralicios como en los conventuales, confirmando, de paso, el alto nivel alcanzado ya por las instituciones académicas virreinales. Finalmente, que la Capilla Real de Palacio a finales del Seiscientos fue una plataforma clave para la promoción personal de los eclesiásticos de origen criollo, quienes en esos años se beneficiaron de las mismas oportunidades que los nacidos en España o en cualquier otro territorio de la Monarquía de los Habsburgo, como lo corroboran los nombramientos que algunos recibieron para ocupar prelacías al otro lado del Atlántico hispano, lo cual debe tenerse en cuenta, tanto como las concesiones de cargos públicos, a la hora de interpretar la lealtad de estos súbditos en el cambio dinástico del siglo XVIII.

\section{BiBLIOGRAFÍA}

Aguirre Salvador, Rodolfo, "La votación de cátedras en la Real Universidad de México: ¿asunto de saber o de poder?", Margarita Menegus Bornemann (coord.), Saber y poder en México: siglos XVI al XX, México, Universidad Nacional Autónoma de México, Centro de Estudios sobre la Universidad, 1997: 171-196.

Alejos Grau, Carmen José, "La contribución de los eclesiásticos novohispanos a la formación de la conciencia nacional mexicana (siglos XVII y XVIII)", Hispania Sacra, LIII/107 (Madrid, 2001): 285-310.

Álvarez-Osorio Alvariño, Antonio, "Facciones cortesanas y arte de buen gobierno en los sermones predicados en la Capilla Real en tiempos de Carlos II", Criticón, 90 (Burdeos, 2004): 99-123.

Basandre, Jorge, El conde de Lemos y su tiempo, Lima, Editorial Huascarán, 1948.

Beristán de Souza, José Mariano, Biblioteca hispanoamericana septentrional. Adiciones y correcciones que a su fallecimiento dejó manuscritas José Fernando Ramírez, México, Fuente Cultural, 1883.

Bridikhina, Eugenia, "La ciudad y la corte como espacios de poder en Hispanoamérica. La Plata colonial", Revista de Indias, LXVII/240 (Madrid, 2007): 553-572.

Burkholder, Mark A. y Chandler, Dewitt Samuel, De la impotencia a la autoridad. La Corona española y las Audiencias en América, 1687-1808, México, Fondo de Cultura Económica, 1984.

Caro Baroja, Julio, La hora navarra del XVIII (Personas, familias, negocios e ideas), Pamplona, Diputación Foral de Navarra-Institución Príncipe de Viana, 1969.

Casado Arboniés, Francisco Javier; Arboniés, Manuel y Gil Blanco, Emiliano, Diccionario de universitarios en la administración americana: arzobispos y obispos 
de Nueva España, 1517-1700, Guadalajara, Diputación Provincial de Guadalajara, 1989.

Coello de la Rosa, Alexandre: "De mestizos y criollos en la Compañía de Jesús (Perú, siglos XVI-XVII)", Revista de Indias, LXVIII/243 (Madrid, 2008): 37-66

Domínguez Casas, Rafael: Arte y etiqueta de los Reyes Católicos. Artistas, residencias, jardines y Bosques, Madrid, Editorial Alpuerto, 1993

Egido, Teófanes: "Los sermones: retórica y espectáculo", Luis Ribot, y Luigi Da Rosa (dirs.), Trabajo y ocio en la Edad Moderna, Madrid, Actas Editoriales, 2001: 87110.

García Bernal, Manuela Cristina: "Las elites capitulares indianas y sus mecanismos de poder en el siglo XVII", Anuario de Estudios Americanos, LVII/1 (Sevilla, 2000): 89-110.

Gómez-Centurión Jiménez, Carlos y Sánchez Belén, Juan A., "La Casa Real durante el siglo XVIII: perspectivas para su estudio", Juan Luis Castellano (ed.), Sociedad, administración y poder en la España del Antiguo Régimen. Hacia una nueva historia institucional, Granada, Universidad de Granada/Diputación Provincial de Granada, 1996: 157-175.

González Acosta, Alejandro, Crespones y campanas tlaxcaltecas en 1701, México, Universidad Nacional de México, 2000.

Herráez Hernández, José María, "Apuntes sobre los graduados indianos por la Universidad abulense del siglo XVII", Cuadernos Abulenses, 18 (Ávila, 1992): 151165 .

Herrero Salgado, Félix, La oratoria sagrada en los siglos XVI y XVII. Predicadores dominicos y franciscanos, Madrid, Fundación Universitaria Española, 1998.

Herzog, Tamar: "La comunidad y su administración. Sobre el valor político, social y simbólico de las residencias de Quito (1653-1753)", Mélanges de la Casa de Velázquez, XXXIV/2 (Madrid, 2004): 161-183.

Klein, H. S, "The Great shift: the Rise of Mexico and the Decline of Peru in the Spanish American Colonial Empire, 1680-1809”, Revista de Historia Económica, XIII/1 (Madrid, 1995): 35-61.

Lohman Villena, Guillermo, El conde de Lemos, virrey del Perú, Sevilla, Escuela de Estudios Hispanoamericanos de la Universidad de Sevilla, 1946.

Lohman Villena, Guillermo, Los americanos en las órdenes nobiliarias (1529-1900), Madrid, CSIC, 1947.

Lohmann Villena, Guillermo, Los regidores perpetuos del cabildo de Lima (15351821). Crónica y estudio de un grupo de gestión, Sevilla, Diputación Provincial de Sevilla, 1983. 
Luna Morerno, Carmen de, "Gobierno interino: la alternancia tripartita en el siglo XVII”, Franciscanos y mundo religioso en México, México, UNAM, 1993: 55-72.

Mantilla, Luis Carlos: "Los presupuestos teóricos del criollismo americano en la obra del colombiano Luis de Betancur y Figueroa (1634)", Revista Complutense de Historia de América, 22 (Madrid, 1996): 121-138.

Maruri Villanueva, Ramón, "Poder con poder se paga: títulos nobiliarios beneficiados en Indias (1681-1821)", Revista de Indias, LXIX/246 (Madrid, 2009): 207-240.

Negredo del Cerro, Fernando, "La Capilla Real como escenario de la lucha política. Elogios y ataques al valido en tiempos de Felipe IV", Juan José Carreras, y Bernardo J. García García (eds.), La Capilla Real de los Austrias. Música y ritual de corte en la Europa Moderna, Madrid, Fundación Carlos Amberes, 2001: 323-344.

Negredo del Cerro, Fernando, Los predicadores de Felipe IV. Corte, intrigas y religión en la España del Siglo de Oro, Madrid, Actas Editorial, 2006.

Ochoa Campos, Moisés: Juan Ignacio María de Castorena y Ursúa y Goyeneche, primer periodista mexicano, México, Publicaciones de la Secretaría de Hacienda y Crédito Público, 1944.

Pazos Pazos, María Luisa J, El ayuntamiento de la ciudad de México en el siglo XVII: Continuidad institucional y cambio social, Sevilla, Diputación Provincial, 1999.

Puente Brunke, José de la, "Codicia y bien público: los ministros de la Audiencia en la Lima seiscientista”, Revista de Indias, LXVI/236 (Madrid, 2006): 133-148.

Rizo-Patrón Boylan, Paul, "La nobleza de Lima en tiempos de los Borbones", Bulletin de l'Institut Français d'Etudes Andines, 19/1 (Lima, 1990): 129-163.

Robledo Estaire, Luis, "La Capilla Real entre Felipe el Hermoso y Felipe II: su influencia en la música española”, W Thomas y R. A. Verdonk (eds.), Encuentros en Flandes. Relaciones e intercambios hispanoflamencos a inicios de la Edad Moderna, Madrid, Lawen University Press, 2000: 303-304.

Robledo Estaire, Luis, "Estructura y función de la capilla musical en la Corte de Felipe II", Juan José Carreras y Bernardo J. García García (eds.), La Capilla Real de los Austrias. Música y ritual de corte en la Europa moderna, Madrid, Fundación Carlos de Amberes, 2001: 195-206.

Robledo Estaire, Luis, "El cuerpo como discurso: retórica, predicación y comunicación no verbal en Caramuel”, Criticón, 84-85 (Burdeos, 2002): 145-164.

Rodríguez de la Flor, Fernando R, La península metafísica. Arte, literatura y pensamiento en la España de la Contrarreforma, Madrid, Editorial Biblioteca Nueva, S. L., 1999.

Rubial García, Antonio, Una monarquía criolla (la provincia agustina de México en el siglo XVII), México, Conaculta, 1990. 
Rubio Merino, Pedro, Don Diego Camacho y Avila: arzobispo de Manila y de Guadalajara de México, 1695-1712, Sevilla, Escuela de Estudios Hispano-Americanos, 1958.

Saavedra Zapater, Juan Carlos y Sánchez Belén, Juan A, "La Capilla Real de Felipe V durante la Guerra de Sucesión", Homenaje a Antonio de Bethencourt Massieu, Las Palmas de Gran Canaria, Cabildo Insular de Gran Canaria, 1995, vol III: 367-401.

Saavedra Zapater, Juan Carlos y Sánchez Belén, Juan A, "La hacienda de la Capilla Real durante el reinado de Felipe V", Carlos Gómez-Centurión Jiménez y Juan A. Sánchez Belén (eds.), La herencia de Borgoña. La hacienda de las Reales Casas durante el reinado de Felipe V, Madrid, Centro de Estudios Políticos e Institucionales, 1998: 121-155.

Saavedra Zapater, Juan Carlos, El primer reformismo borbónico en palacio: La Capilla Real (1700-1750), Madrid, UNED, 2005.

Saavedra Zapater, Juan Carlos, "Redes familiares y clientelares americanas en España: Los capellanes y predicadores de la Capilla Real de Palacio (1650-1700)", Juan Jesús Bravo Caro y Juan Sanz Sampelayo (eds.), Población y grupos sociales en el Antiguo Régimen, Málaga, Fundación Española de Historia Moderna, 2009, vol 2: 1223-1240.

Sánchez Belén, Juan A, "La Capilla Real de palacio a finales del siglo XVII", Juan José Carreras y Bernardo J. García García (eds.), La Capilla Real de los Austrias. Música y ritual de corte en la Europa moderna, Madrid, Fundación Carlos de Amberes, 2001: 411-447.

Santa Eugenia, Francisco Javier, "Los americanos frente a la Monarquía. El criollismo y la naturaleza española", Antonio Álvarez-Ossorio Alvariño y Bernardo J. García García (eds.), La monarquía de las naciones: patria, nación y naturaleza en la monarquía de España, Madrid, Fundación Carlos de Amberes, 2004: 77-92.

Sanz Tapia, Ángel, "El acceso a los cargos de gobierno de la audiencia de Quito (1701-1750)", Anuario de Estudios Americanos, 63/2 (Madrid, 2006): 49-73.

Sanz Tapia, Ángel, ¿Corrupción o necesidad? La venta de cargos de gobierno americanos bajo Carlos II (1674-1700), Madrid, CSIC, 2009.

Sarabia Viejo, María Justina y Vila Vilar, Enriqueta, Cartas de cabildos hispanoamericanos: audiencia de México (siglos XVI y XVII), Sevilla, CSIC/Diputación Provincial de Sevilla, 1985.

Simón Díaz, José, Bibliografia de la literatura hispánica, Madrid, CSIC, 1960-1984.

Vargas Ugarte, Rubén, Don Pedro Antonio Fernández de Castro, X Conde de Lemos y virrey del Perú, Lima, Editorial Universitaria, 1965.

Fecha de recepción: 9 de octubre de 2011.

Fecha de aceptación: 26 de enero de 2013. 


\section{Creole Priests in the Spanish Royal Chapel: A Powerful Elite during the Reign of Carlos II (1665-1700)}

The present work analyzes the motives and reasons that lead the Creole elites of the American viceroyalties to request employment as honor chaplains and preachers in the King's Royal Chapel during the final decades of the $17^{\text {th }}$ century. This study also analyzes the selection mechanisms that were established by the Crown to facilitate the access to the institution, particularly those related to racial purity and nobility of the lineage of the applicants to one of those positions.

KeY WORDs: ecclesiastical; creole; elites; Royal Chapel; Carlos II. 